\title{
Molecular Comparison Between FMDV Causing Recent Outbreaks In Egypt And The Used Vaccine Strains
}

\author{
El-Bakry M Ismail*, Abd Al-Motty M Shawky**, Farag M Amer** and \\ Ahmed F Saudy** \\ *Virology Department, Faculty of Veterinary Medicine, Zagazig University, Egypt
**FMD Department, Veterinary Serum and Vaccine Research Institute, Abbassia, Cairo.
}

\section{ABSTRACT}

Foot and mouth disease virus (FMD) had taken an enzootic form in Egypt since 1950, since then continues outbreaks occurs, serotype A, O and SAT2 are the most common serotypes isolated in Egypt. In this study, The suspected isolates were diagnosed and typed using an RT - PCR test. The nucleotide sequences of the VP1-coding region was determined and phylogenetic analysis was performed. The results showed that FMDV serotype O were confirmed to be serotype O topotype ME-SA in all localities, while the isolated type A during 2009 was confirmed to be serotype A topotype Africa, while the isolated type A during 2010 and 2011 belong to the Asia topotype and FMDV serotype SAT was confirmed to be SAT2 topotype VII.

\section{INTRODUCTION}

Foot and mouth disease virus (FMDV) is the causative agent of an acute devastating, febrile, infectious and highly contagious viral disease of cattle, sheep, goat, swine and other wild cloven-footed animals( $(1)$. It's characterized by vesicle formation on the dorsum of the tongue, nose, muzzle, and coronary bands. Infected animals develop salivation, lameness, drop in milk production, with the high morbidity rate in adult animals and mortality rate reach to $50 \%$ in young animals(2).It may be transmitted primarily by contact and aerosol in addition to the ingestion of contaminated matter and the use of contaminated vaccines and/or semen (3).FMDV is a member of Family Picornaviridae, Genus Aphthovirus. It has single stranded positive sense RNA molecule of about 8.2 kilo bases (kb). The virus contains four structural proteins (1A, 1B, 1C, and 1D) of the virus capsid and eight non structural (NS) proteins $(2 \mathrm{~A}, 2 \mathrm{~B}, 2 \mathrm{C}, 3 \mathrm{~A}, 3 \mathrm{~B}, 3 \mathrm{C}, 3 \mathrm{D}$ and $\mathrm{L}$ protein) involved in the life cycle of the virus inside the infected cells (4). Seven immunological serotypes of FMDV were recorded, which are $\mathrm{O}, \mathrm{A}, \mathrm{C}, \mathrm{SAT}_{1}, \mathrm{SAT}_{2}$,
$\mathrm{SAT}_{3}$ and Asia1 (5).There was no antigenic relation between the seven serotype and the infection with one serotype doesn't protect the animal against the other serotypes and they can only be differentiated in the laboratory (6).The nucleotide sequence of the viral RNA has allowed unequivocal characterization of the genetic relationships between strains. Phylogenetic tree based on the VP1 (1D) region of FMDV is widely used for genetic characterization because of its significance for virus attachment and entry, protective immunity, and serotype specificity(7).Control of FMDV has been based on large scalevaccinations with whole inactivated virus vaccines, limitationof animal movements and destruction of herds exposed to thevirus (8). In Egypt, a local monovalent vaccine of strain $\mathrm{O}_{1} / 3 / 93$ FMDV routinely used to vaccinate dairy cattle, buffaloes and fattening bulls. By the occurring of the last outbreak of FMDV type $\mathrm{A}$ in 2006 , there is a need to produce a good quality bivalent inactivated FMDV vaccine containing strains $\mathrm{A} / 1 /$ Egypt/2006 and $\mathrm{O}_{1} / 3 / 93$ to control both field types of FMDV.Identifying and quantifying the importance of sites that predict viral strain 
cross-reactivity not just for single viruses but across entire serotypes can help in the design of vaccines with better targeting and broader coverage(9). This approach quickly and cheaply increases both our understanding of antigenic relationships and our power to control disease. Thus, in the present study, we investigated the molecular relationship between FMDV causing recent outbreaks in Egypt and the used vaccinal strains.

\section{MATERIAL AND METHODS}

Samples

Epithelial tissue samples (ET)and Oesophageal pharyngeal fluid (OP) were collected during the course of the study between 2009 and 2012 (Table1).These samples were placed in a virus transport medium, composed of equal amounts of glycerol and phosphate buffer containing antibiotic mixture in a final concentration of $100 \mathrm{IU} / \mathrm{ml}$ penicillin, 100ug $/ \mathrm{ml}$ streptomycin and $40 \mathrm{mg} / \mathrm{ml}$ gentamycin and $\mathrm{pH}$ in the range $\mathrm{pH} 7.2-7.6$, and were stored at $-70^{\circ} \mathrm{C}$ until used (10).

Table 1. Number and types of samples collected from naturally infected animals in different Egyptian governorates during the study

\begin{tabular}{cccccc}
\multirow{2}{*}{ province } & Year of & \multicolumn{4}{c}{ Types of samples } \\
\cline { 3 - 6 } & Sampling & \multicolumn{3}{c}{ T.E } & O.P \\
\cline { 3 - 6 } & 2009 & 5 & Buffalo & 10 & Species \\
\hline \multirow{2}{*}{ El Sharquia } & 2010 & 8 & Buffalo & 15 & F.C \\
& 2011 & 18 & Cattle & 15 & F.C \\
& 2012 & 32 & Cattle & -- & -- \\
El Menoufia & 2009 & 5 & Buffalo & 15 & F.C \\
& 2010 & 8 & Cattle & 18 & F.C \\
& 2011 & 12 & Cattle & 11 & F.C \\
El Qaliubia & 2012 & 28 & Cattle & -- & -- \\
& 2009 & 11 & Cattle & 18 & F.C \\
Fayoum & 2010 & 5 & Buffalo & 15 & F.C \\
El Garbia & 2011 & 18 & Cattle & 10 & F.C \\
El Suiz & 2012 & 28 & Cattle & -- & -- \\
Alex & 2012 & 11 & Cattle & -- & -- \\
El Menia & 2012 & 30 & Cattle & -- & -- \\
Kafr El Shaik & 2012 & 5 & Cattle & 3 & F.C \\
Total & 2012 & 10 & Cattle & 8 & F.C \\
& 2012 & 10 & Buffalo & -- & -- \\
\hline & 2012 & 8 & Cattle & -- & --
\end{tabular}

(ET)Epithelial tissue samples

(OP)Oesophageal pharyngeal fluid 
Genomic RNA Extraction

RNA was extracted from Epithelial tissue samples(ET) and Oesophageal pharyngeal fluid (OP) using GeneJET ${ }^{\mathrm{TM}}$ RNA Purification Kit (Fermentas) following the manufacturer's instructions.

\section{RT-PCR amplification}

PCR for amplification VP1 (ID) of FMDV specific fragments were performed using Primers describedpreviously (11) (Table 2). It was carried out according to the manufacture's protocol to perform the reverse transcription and the subsequent PCR in a single reaction tube. The RT-PCR program consisted of 30 min at $45^{\circ} \mathrm{C}$ and $5 \mathrm{~min}$ at $94^{\circ} \mathrm{C}$ and a threestep cycling protocol was used as $94^{\circ} \mathrm{C}$ for 30 $\mathrm{s}, 68^{\circ} \mathrm{C}$ for $1 \mathrm{~min}$ and $72^{\circ} \mathrm{C}$ for $1 \mathrm{~min}$ for 35 cyclesand cycle of final extension at $72^{\circ} \mathrm{C}$ for $10 \mathrm{~min}$. Negative controls were included in each assay for detection of any contamination using Maxime ${ }^{\mathrm{TM}}$ RT-PCR PreMix (Fermentas,USA). Five microliters of amplified PCR products were separated by 1 $\%$ ethidium bromide strained agarose gel electrophoresis at $120 \mathrm{~V}$ for20 min. 1-kbp DNA Marker (Fermentas, USA) was used as standard and the amplified products were visualized using ultraviolet light transilluminator.

Table 2. Oligonucleotide primers used for RT-PCR reaction for detection of VP1 (ID) of FMDV serotypes

\begin{tabular}{cccc} 
Primer Name & Sequence (5'- $\left.\mathbf{3}^{\prime}\right)$ & nmoles & $\begin{array}{c}\text { Serotype } \\
\text { specificity }\end{array}$ \\
\hline G.FMDV-3R & AGCTTGTACCAGGGTTTGGC & 53.11 & For all types \\
O402-3F & GCTGCCTACCTCCTTCAA & 12.80 & O \\
A732-3F & GTCATTGACCTCATGCAGACCCAC & 8.94 & A \\
C.SAT257-3F & GGCGTTGAGAAACAACTGTG & 9.98 & C. SAT \\
C596-3F & GTTTCTGCACTTGACAACACA & 10.09 & C \\
Asia292-3F & GACACCACTCAGGACCGCCG & 10.67 & Asia \\
\hline C-SAT, Common SAT primer & &
\end{tabular}

Purification and sequencing of PCR product

PCR products were purified using Gene JET PCR purificationkit (Fermentas) and resuspended in 50ul $\mathrm{H}_{2} \mathrm{O}$. Each purified amplicon was sequenced in both forward and reverse directions using the amplification primers. The sequencing reaction was performed in an automatedsequencer (Macrogen Inc., Korea ABI 3730XL DNA analyzer). The accession numbers of reference sequences obtained from the Genbank database were listed in (Tables 3\&4).

Nucleotide sequencing and phylogeneticanalysis

Sequencing of PCR product was performed by Macrogen, Korea. Comparative analyses and phylogenetic trees were performed using MEGA5 program(12) 
Table 3. Details of reference FMDV serotype $\mathrm{O}$ used for alignments and sequence analysis of FMDV serotype $\mathrm{O}$ VP1 gene of recent isolates

\begin{tabular}{|c|c|c|c|c|}
\hline & Accession No & Description & Location & Species \\
\hline 1. & gi|413968623|JX666333.1 & O/EGY/ALX/2011 & Egypt & Cattle \\
\hline 2. & gi|391234182|JQ837833.1 & O/EGY/MNF-2009 & Egypt & Cattle \\
\hline 3. & gi|76564171|DQ164871.1 & O1/Sharquia/EGY/72 & Egypt & Cattle \\
\hline 4. & gi| $183579037 \mid E U 553840.1$ & $\mathrm{O} / \mathrm{EGY} / 3 / 93$ & Egypt & Cattle \\
\hline 5. & gi|46810902|AY593823.1 & Olmanisa iso87, CG. & Turkey, 1969 & -- \\
\hline 6. & gi|291294194|GU566055.1 & O_SUD/30/2004 & Sudan & Cattle \\
\hline 7. & gi255761952EU919246.1 & O/UGA/6/76, P1 & Uganda & -- \\
\hline 8. & gi|183579051|EU553847.1 & O/SAU/29/93 & KSA & CCS \\
\hline 9. & gi|76564415|DQ164993.1 & O/UAE/4/99 & UAE & Antelope \\
\hline 10. & gi|220898645|FJ561317.1 & O/JOR/6/2006 & Jordan & Cattle \\
\hline 11. & gi|46810918|AY593831.1 & O UK2001-ED & UK & - \\
\hline
\end{tabular}

Table 4. Details of reference FMDV serotype A used for alignments and_sequence analysis of FMDV serotype AVP1 gene of recent isolates

\begin{tabular}{|c|c|c|c|c|}
\hline & Accession No & Description & Location & Species \\
\hline 1. & gi|122938368|EF159977.1 & A/Egy/2006/iso_Ism & Egypt: Ismailia & Cattle \\
\hline 2. & gi|145573118|EF208757.1 & $\mathrm{A} / \mathrm{EGY} / 1 / 2006^{-}$ & Egypt: Ismailia & Bovine \\
\hline 3. & gi| $145573116 \mid$ EF208756.1 & $\mathrm{A} / \mathrm{EGY} / 1 / 72$ & Egypt: Alex & Bovine \\
\hline 4. & gi| $258590106 \mid$ FJ798150.1 & $\mathrm{A} / \mathrm{ETH} / 4 / 2007$ & Ethiopia & Cattle \\
\hline 5. & gi| $145573150 \mid$ EF208773.1 & $\mathrm{A} / \mathrm{KEN} / 29 / 2005$ & Kenya: Embu, & Bovine \\
\hline 6. & gi|291294218|GU566067.1 & $\mathrm{SUD} / 2 / 84$ & Sudan & Cattle \\
\hline 7. & gi|354551401|JN099696.1 & A/IRQ/09 -4247 & Iraq: Baghdad & \\
\hline 8. & gi|225032249|FJ755037.1 & A/IRN/27/2005 & Iran & Cattle \\
\hline 9. & gi|225032349|FJ755087.1 & $\mathrm{A} / \mathrm{SAU} / 16 / 2005$ & Saudi Arabia & Cattle \\
\hline 10. & gi|225032419|FJ755122.1 & A/TUR/10/2007 & Turkey & Cattle \\
\hline 11. & gi|225032335|FJ755080.1 & $\mathrm{A} / \mathrm{JOR} / 4 / 2006$ & Jordan & Cattle \\
\hline 12. & gi|225032195|FJ755010.1 & $\mathrm{A} / \mathrm{BAR} / 6 / 2008$ & Bahrain & Cattle \\
\hline
\end{tabular}

Table 5. Details of reference FMDV serotypeAT2 used for alignments and sequence analysis of FMDV serotype SAT2 VP1 gene of recent isolates

\begin{tabular}{lllll}
\multicolumn{1}{c}{ Accession No } & \multicolumn{1}{c}{ Description } & \multicolumn{1}{c}{ Location } & Species \\
\hline 1. & gi|399221028|JX014256.1 & PAT/1/2012, C.G & Palestinian, Rafa" & Cattle \\
2. & gi|399221026|JX014255.1 & EGY/9/2012, C.G & El-Suiz & Cattle \\
3. & gi|408358898|JX570620.1 & EGY/5/2012 & Menia Governorate & Cattle \\
4. & gi|408358920|JX570631.1 & LIB/1/2003 & Sabratah, ZawiyaDistr & Cattle \\
5. & gi|408358928|JX570635.1 & LIB/41/2012 & Abu Attni, Benghazi, & Cattle \\
6. & gi|38046553|AY343967.1 & UGA/9/95 & Uganda & Bovine \\
7. & gi|291294228|GU566072.1 & SUD/1/2008 & Sudan & Cattle \\
8. & gi|301088148|HM623697.1 & K77/96 & Kenia- Nakuru & Cattle \\
9. & gI|258590128|FJ798161.1 & ETH/2/2007 & Ethiopia & Cattle \\
10. & gi|28625607|AF367135.1 & SAU/6/2001 & Saudi Arabia & Cattle \\
11. & gi|408358880|JX570611.1 & BAR/12/2012 & Bahrain & Cattle \\
\hline & & & &
\end{tabular}




\section{RESULTS}

Detection and typing of FMDV new isolates by RT-PCR using specific primers

Each sample was tested against five specific primers to serotype O, A, C, Common
SAT and ASIA. Samples are loaded on agarose gel without adding a loading-dye buffer and perform electrophoresis. Positive samples were seen at the position specific for each serotype ( Table $6 \&$ photo1).

Table 6.Typing of FMDV new isolates by RT-PCR using specific primers

\begin{tabular}{lccccccc}
\multicolumn{1}{c}{ province } & $\begin{array}{c}\text { No of } \\
\text { Sampling }\end{array}$ & $\begin{array}{c}\text { Date of } \\
\text { Sampling }\end{array}$ & O & A & C & C.SAT & ASIA \\
\hline \multirow{3}{*}{ El Sharquia } & 15 & 2009 & + & + & - & - & - \\
& 23 & 2010 & + & + & - & - & - \\
& 33 & 2011 & - & + & - & - & - \\
& 32 & 2012 & - & - & - & + & - \\
El Menoufia & 20 & 2009 & - & + & - & - & - \\
& 26 & 2010 & + & + & - & - & - \\
& 23 & 2011 & - & + & - & - & - \\
& 28 & 2012 & - & - & - & + & - \\
El Qaliubia & 29 & 2009 & + & + & - & - & - \\
& 20 & 2010 & + & + & - & - & - \\
El Fayoum & 28 & 2011 & - & + & - & - & - \\
El Garbia & 28 & 2012 & - & - & - & + & - \\
El Suiz & 11 & 2012 & - & - & - & + & - \\
Alex & 30 & 2012 & - & - & - & + & - \\
El Menia & 8 & 2012 & - & - & - & + & - \\
Kafr El Shaik & 18 & 2012 & - & - & - & + & - \\
\hline C-SAT, Common SAT primer & 10 & 2012 & - & - & - & + & - \\
& 8 & 2012 & - & - & - & + & - \\
\hline
\end{tabular}



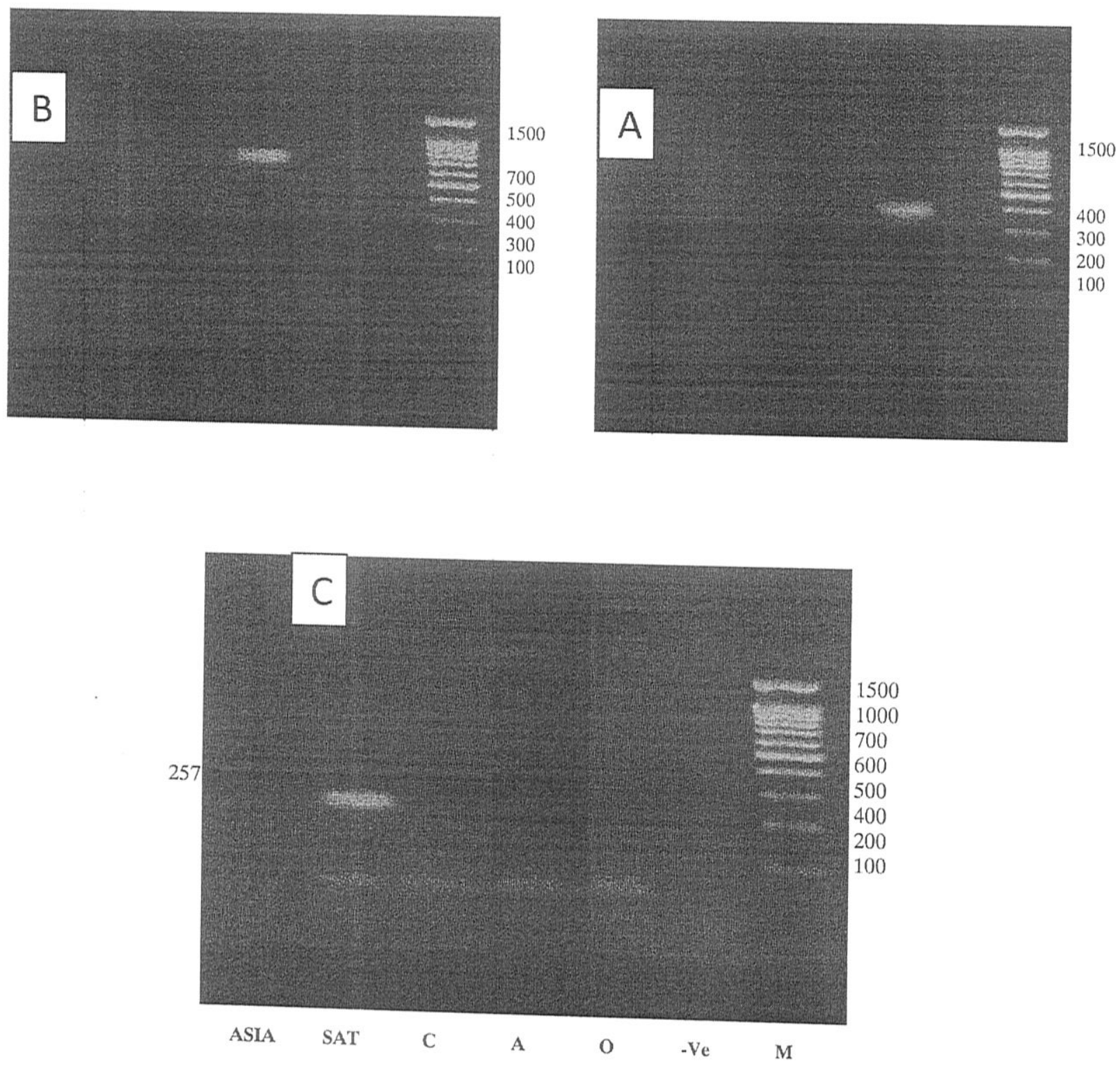

Photo 1. RT-PCR amplification for detection and typing of FMDV new isolates of the present study. (A)Serotype $O$ detected at $402 \mathrm{bp}$ in lane O, (B)serotype A detected at 732 bp in lane A, and (C)serotype SAT detected at 257bp in lane SAT. Lane M, 1500bp DNA ladder, Lane -ve, negative control. Lane 1 O primer, Lane 2 A, Lane 3 C, Lane 4 CSAT, AND Lane 5 ASIA primer. 
Alignment and phylogenetic analysis of VP1 gene of FMDV serotype $O$.

The nucleotide sequence alignment analysis of VP1 gene was performed between the recently isolated Egyptian FMDV serotype $\mathrm{O}$ and 11 reference strains by the Clustal W method using MEGA5 program (Table 7\& Figure1).

Table 7. Estimates of evolutionary divergence between sequences of FMDV serotype O VP1 gene of recent isolates and the reference FMDV serotype $O$ strains

\begin{tabular}{|c|c|c|c|c|c|c|c|c|c|}
\hline \multirow{2}{*}{\multicolumn{2}{|c|}{ Strains description }} & \multicolumn{4}{|c|}{ No of base difference } & \multicolumn{4}{|c|}{$\%$ of identity } \\
\hline & & 1 & 2 & 3 & 4 & 1 & 2 & 3 & 4 \\
\hline 1. & O/Egy/Sharquia/2009 & & 3.0 & 72.0 & 72.0 & & 99.24 & 81.73 & 81.73 \\
\hline 2. & O/Egy/Qaliubia/2009 & 3.0 & & 75.0 & 75.0 & 99.24 & & 80.96 & 80.96 \\
\hline 3. & O/Egy/Sharquia/2010 & 72.0 & 75.0 & & 0.0 & 81.73 & 80.96 & & 100 \\
\hline 4. & O/Egy/Menoufia/2010 & 72.0 & 75.0 & 0.0 & & 81.73 & 80.96 & 100 & \\
\hline 5. & O/EGY/ALX/2011 & 35.0 & 38.0 & 68.0 & 68.0 & 91.12 & 90.36 & 82.74 & 82.74 \\
\hline 6. & O/EGY/MNF-2009 & 66.0 & 69.0 & 3.0 & 3.0 & 83.25 & 82.49 & 99.24 & 99.24 \\
\hline 7. & O1/Sharquia/EGY/72 & 17.0 & 20.0 & 56.0 & 56.0 & 95.69 & 94.92 & 85.79 & 85.79 \\
\hline 8. & $\mathrm{O} / \mathrm{EGY} / 3 / 93$ & 60.0 & 63.0 & 53.0 & 53.0 & 84.77 & 84.01 & 86.55 & 86.55 \\
\hline 9. & O1manisa iso87 CG & 45.0 & 48.0 & 54.0 & 54.0 & 88.58 & 87.82 & 86.29 & 86.29 \\
\hline 10. & O_SUD/30/2004 & 59.0 & 62.0 & 69.0 & 69.0 & 85.03 & 84.26 & 82.49 & 82.49 \\
\hline 11. & O/UGA/6/76 & 50.0 & 53.0 & 56.0 & 56.0 & 87.31 & 86.55 & 85.79 & 85.79 \\
\hline 12. & $\mathrm{O} / \mathrm{SAU} / 29 / 93$ & 56.0 & 59.0 & 52.0 & 52.0 & 85.79 & 85.03 & 86.8 & 86.8 \\
\hline 13. & $\mathrm{O} / \mathrm{UAE} / 4 / 99$ & 60.0 & 63.0 & 29.0 & 29.0 & 84.77 & 84.01 & 92.64 & 92.64 \\
\hline 14. & O/JOR/6/2006 & 65.0 & 68.0 & 14.0 & 14.0 & 83.5 & 82.74 & 96.45 & 96.45 \\
\hline 15. & O_UK2001-FB CG. & 63.0 & 66.0 & 32.0 & 32.0 & 84.01 & 83.25 & 91.88 & 91.88 \\
\hline
\end{tabular}

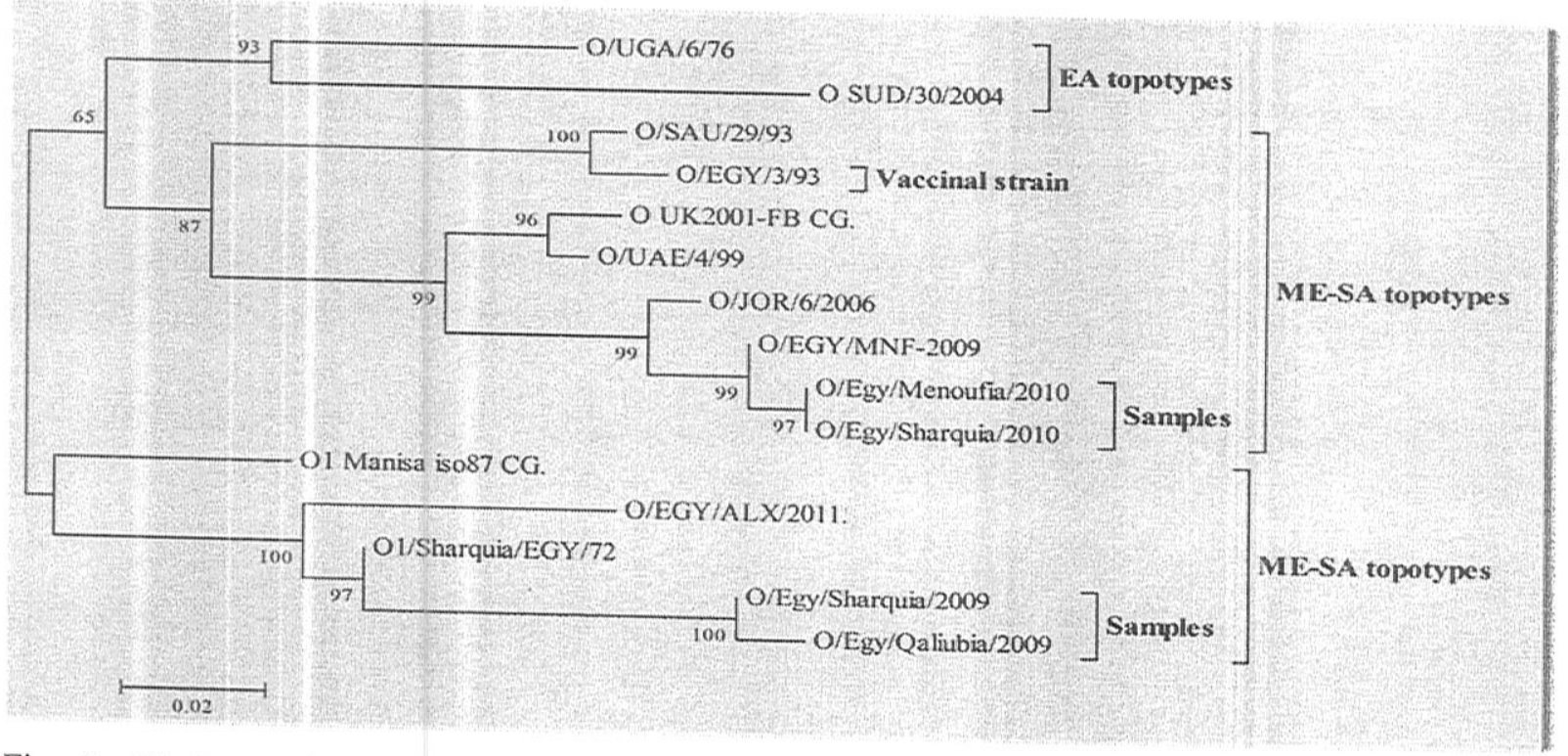

Fig. 1. Phylogenetic analysis of FMDV serotypes O based on VP1 gene nucleotide sequences. Phylogenetic tree was constructed via multiple alignments of 15 different nucleotide sequences. The tree was analyzed by neighbor-joining (N-J) analysis with bootstrapping (1000). 
Alignment and phylogenetic analysis of VP1 gene of FMDV serotype A

The nucleotide sequence alignment analysis of VP1 gene were performed between the recently isolated Egyptian FMDV and 12 reference strains by Clustal W method using MEGA5 program (Table 8 \& Figure2).

Table 8. Estimates of evolutionary divergence between sequences of FMDV serotype A VP1 gene of recent isolates and the reference FMDV serotype A strains

\begin{tabular}{|c|c|c|c|c|c|c|c|}
\hline & \multirow{2}{*}{ Strains description } & \multicolumn{3}{|c|}{ No of base difference } & \multicolumn{3}{|c|}{$\%$ of identity } \\
\hline & & 1 & 2 & 3 & 1 & 2 & 3 \\
\hline 1. & A/Egy/Sharquia/2009 & & 151.0 & 151.0 & & 77.76 & 77.76 \\
\hline 2. & A/Egy/Menoufia/2010 & 151.0 & & 1.0 & 77.76 & & 99.85 \\
\hline 3. & A/Egy/Qaliubia/2011 & 151.0 & 1.0 & & 77.76 & 99.85 & \\
\hline 4. & A/EGY/1/2006 & 7.0 & 145.0 & 145.0 & 98.97 & 78.77 & 78.77 \\
\hline 5. & A/Egy/2006/iso_Ism & 8.0 & 149.0 & 150.0 & 98.82 & 78.18 & 78.04 \\
\hline 6. & $\mathrm{~A} / \mathrm{EGY} / 1 / 72$ & 108.0 & 138.0 & 138.0 & 84.09 & 79.8 & 79.8 \\
\hline 7. & A_ETH/4/2007 & 33.0 & 140.0 & 140.0 & 95.14 & 79.5 & 79.5 \\
\hline 8. & $\mathrm{~A} / \mathrm{KEN} / 29 / 2005$ & 22.0 & 144.0 & 144.0 & 96.76 & 78.92 & 78.92 \\
\hline 9. & $\mathrm{~A} / \mathrm{SUD} / 2 / 84$ & 109.0 & 150.0 & 150.0 & 83.95 & 78.04 & 78.04 \\
\hline 10. & A/IRQ/09-4247 & 147.0 & 16.0 & 17.0 & 78.35 & 97.66 & 97.51 \\
\hline 11. & A/IRN/27/2005 & 145.0 & 40.0 & 40.0 & 78.65 & 94.14 & 94.14 \\
\hline 12. & A/SAU/16/2005 & 147.0 & 40.0 & 40.0 & 78.35 & 94.14 & 94.14 \\
\hline 13. & A/TUR/10/2007 & 145.0 & 43.0 & 43.0 & 78.65 & 93.7 & 93.7 \\
\hline 14. & A/JOR/4/2006 & 143.0 & 44.0 & 44.0 & 78.94 & 93.56 & 93.56 \\
\hline 15. & $\mathrm{~A} / \mathrm{BAR} / 6 / 2008$ & 140.0 & 21.0 & 21.0 & 79.38 & 96.93 & 96.93 \\
\hline
\end{tabular}

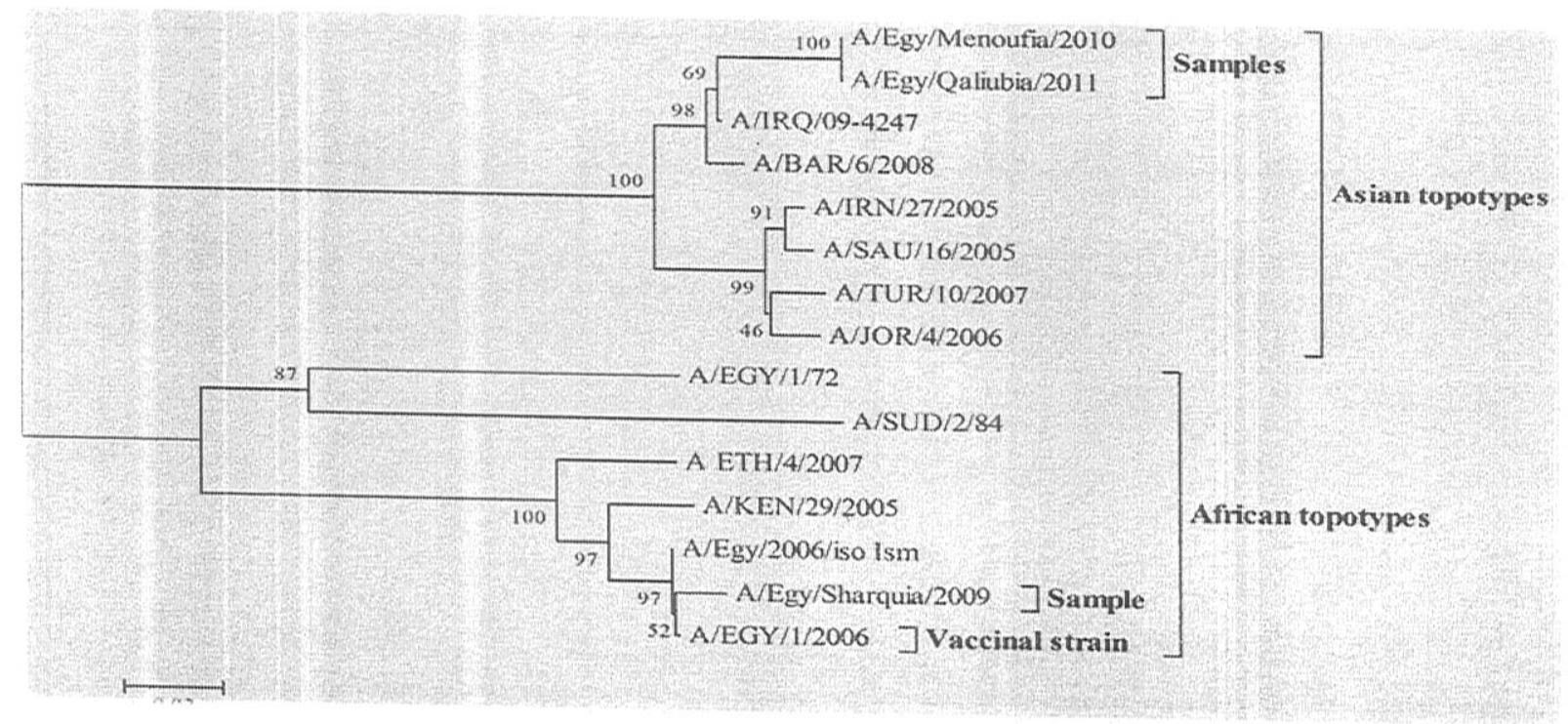

Fig. 2. Phylogenetic analysis of FMDV serotypes A based on VP1 gene nucleotide sequences. Phylogenetic tree was constructed via multiple alignments of 15 different nucleotide sequences. The tree was analyzed by neighbor-joining $(\mathrm{N}-\mathrm{J})$ analysis with bootstrapping $(1000)$. 
Alignment and phylogenetic analysis of VP1 gene of FMDV serotype SAT2

The nucleotide sequence alignment analysis of VP1 gene were performed between the recently isolated Egyptian FMDV and 11 reference strains by Clustal $W$ method using MEGA5 program (Table 9\& Figure3).

Table 9. Estimates of evolutionary divergence between sequences of FMDV serotype SAT2 VP1 gene of recent isolates and the reference FMDV serotype SAT2 strains

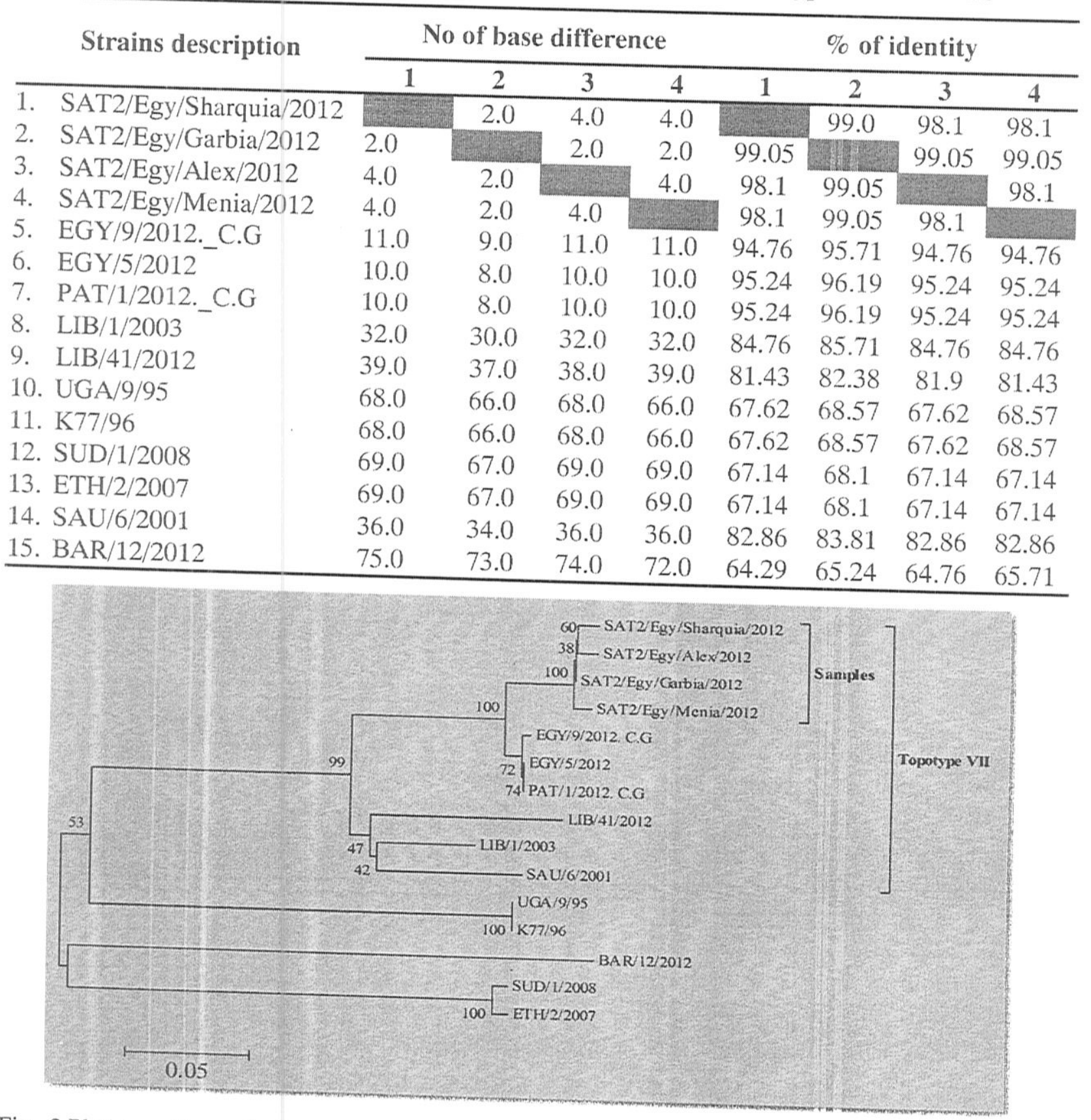

Fig. 3.Phylogenetic analysis of FMDV serotypes SAT2 based on VP1 gene nucleotide sequences.
Phylogenetic tree was constructed via Phylogenetic tree was constructed via multiple alignments of 15 different nucleotide sequences. The tree was analyzed by neighbor-joining (N-J) analysis with bootstrapping (1000). 


\section{DISCUSSION}

In the present study,252Epithelial tissue samples(ET) and 1380esophageal pharyngeal fluid (OP) samples were collected from 9 different Egyptian governorates during the period of 2009 to 2012. During 2009, FMDV serotype $\mathrm{O}$ was isolated in samples collected from El Sharquia, El Qaliubia and it was not isolated from El Menoufia while, FMDV serotype A was isolated in samples collected from El Sharquia, El Menoufia and El Qaliubia. The isolated serotypes were sequenced and the identified sequences fromEl Sharquia and El Qaliubia were named O/Egy/ Sharquia/2009, A/Egy/Sharquia/2009 and O/Egy/Qaliubia/ 2009 respectively. Comparative alignment and phylogenetic analysis reveal that, the isolated FMDV serotype $O$ were confirmed to be serotype $\mathrm{O}$ topotype ME-SA PanAsia and they were highly related to FMDV strain (O1/Sharquia/EGY/72) isolated from Egypt, (O/EGY/ALX/2011) isolated from Egypt in 2011 and the isolated O strains has $84.5 \%$ nucleotide identity to the vaccinal strains (O/EGY/3/93) isolated in Egypt 1993 and the isolated FMDV serotype A was confirmed to be serotype A topotype Africa and it was highly related to strain $(\mathrm{A} / \mathrm{EGY} / 4 / 2006)$ isolated from Egypt in 2006, (A/KEN/29/2005) isolated from Kenya in 2005 and the isolated A strain has 98.97\% nucleotide identity to the vaccinal strains (A/EGY/1/2006) isolated in Egypt 2006. These findings were agreed with previous study (13) which reported that, FMD type O was detected in samples collected in 2009, it belongs to the ME-SA topotype, PanAsia-2 sublineage. FMD type $\mathrm{A}$ was detected in samples collected in 2009, it belongs to the Africa topotype, G-VII ${ }^{\text {KEN-05 }}$ sublineage. During 2010, FMDV serotype O was isolated in samples collected from El Sharquia, El Menoufia and El Qaliubia and FMDV serotype A was isolated in samples collected from $\mathrm{El}$ Sharquia, El Menoufia and El Qaliubia. the identified sequences from El Sharquia and El Menoufia was named O/Egy/Sharquia/2010, O/Egy/ Menoufia/2010 and A/Egy/ Menoufia/2010 respectively. Comparative alignment and phylogenetic analysis reveal that, the isolated FMDV serotype $\mathrm{O}$ are confirmed to be serotype O topotype ME-SA PanAsia and it was highly related to FMDV strains (O/EGY/15BH-2009) isolated from Egypt in 2009, (O/EGY/ FYM/ 2011) isolated from Egypt in 2011 and $(\mathrm{O} / \mathrm{JOR} / 6 / 2006)$ isolated from Jordon in 2006 and the isolated O strains has $86.5 \%$ nucleotide identity to the vaccinal strains (O/EGY/3/93) isolated in Egypt 1993, and the isolated FMDV serotype $A$ are confirmed to be serotype A topotype Asia and it was highly related to FMDV strains (A/IRQ/09-4247) isolated from Iraq in 2009 and (A/IRN/5/2006) isolated from Iran in 2006 and the isolated A strains has $78.7 \%$ nucleotide identity to the vaccinal strains (A/EGY/1/2006) isolated in Egypt 2006. FMD type A was detected in samples collected in 2010 it belongs to Asia topotype, Iran- ${ }^{05 B A R-08}$ sublineage(14). During 2011, FMDV serotype A was isolated in $100 \%$ of samples collected from 3 governorates and no other serotype were detected.the identified sequences from El Qaliubia was named A/Egy/Qaliubia/2011. Comparative alignment and phylogenetic analysis revile that, the isolated FMDV are confirmed to be serotype A topotype Asia and it was highly related to FMDV strains (A/IRQ/09-4247) isolated from Iraq in 2009 and (A/IRN/5/2006) isolated from Iran in 2006 and the isolated A strains has $78.7 \%$ nucleotide identity to the vaccinal strains (A/EGY/1/2006) isolated in Egypt 2006. FMD type A was detected in samples collected in 2010 and 2011 belong to the Asia topotype, Iran- ${ }^{05 B A R-08}$ sublineage (14).. And disagree with it in reporting that, FMD type $\mathrm{O}$ viruses were isolated from three samples collected in 2011 and were genotyped as O/ME-the identified sequences from El Sharquia, El Garbia, Alex and El Menia was named SAT2/Egy/ Sharquia/2012, SAT2/Egy/Garbia/2012, SAT2/ Egy/Alex/2012 and SAT2/Egy/Menia/2012 respectively. Comparative alignment and phylogenetic analysis reveal that, the isolated FMDV are confirmed to be serotype SAT2 topotype - 1 - and they were highly related to each other's with $98.8 \%$ nucleotide identity and they were highly related to all reference FMDV 
strains isolated from Egypt during 2012, (PAT/1/2012) isolated from Palestine in 2012 and (LIB/41/2012) isolated from Libya in 2012.This findings are agree with (14)which reported that, between 18/02/2012 and 26/03/2012, 43 outbreaks of FMD type SAT 2 were reported in Egypt. The Egyptian viruses belonged to SAT2 topotype VII with the Libyan virus.

\section{REFERENCES}

\section{Phologane B S, Dwarka, R M, Haydon, D} $T$, Gerber, $L J$ and Vosloo $W$ (2008). Molecular characterization of SAT-2 footand-mouth disease virus isolates obtained from cattle during a four-month period in 2001 in Limpopo Province, South Africa. Onderstepoort J Vet Res. 2008 Dec; 75 (4):267-77.

2.Ferguson M Neil, Christl A Donnelly and Roy $M$ Anderson (2001): The Foot-andMouth Epidemic in Great Britain: Pattern of Spread and Impact of Interventions. Science, May 11; 292 (5519), 1155-1160.

3.Musser J M (2004): A practitioner's primer on foot-and-mouth disease. J.Am., Vet. Med. Assoc., Apr., 15;224(8):1261-8. Department of Veterinary Pathobiology, College of Veterinary Medicine, Texas A\&M University, College Station, TX 77843-77855.

4.Kitching R P (2002): Problems of diagnosis of foot and mouth disease in domestic animals.In foot and mouth disease, control strategies, symposium proceedings, 2-5 June 2002, Lyons, France: 353-359.

5.Mason, $P$ W, Grubman, $M J$ and Baxt, B (2003): Molecular basis of pathogenesis of foot and mouth disease virus. V. Res., 91: 9-32.

6.Lok-Ting L, Scott M R, Donald P K, Anson, $M L$, Andrew $E S$, Nigel $P F$ and Albert $C$ $Y$ (2007). Detection of foot and mouth disease virus by nucleic acid sequence- based amplification (NACBA), Veterinary Microbiology 126:101-110.

7.Burman A, Clark S, Abrescia N G, Fry E E, Stuart D I and Jackson T (2006): Specificity of the VP1 GH loop of foot-andmouth disease virus for alphavintegrins.J Virol. 2006 Oct; 80(19):9798-810.

8.Brown $F$ (2002): A brief of FMD and its causal agent.In FMD control strategies, symposium proceeding, 2-5 June 2002, Lyon, France: 13-21.

9.Abeer $E M$ and Hegazi A $Z$ (2008): Immune responsce of different farm animals vaccinated with the bivalent FMD vaccine. Second Virological Conference. Doki. Cairo. Egypt.

10.OlE (2009): Foot and mouth disease. In: OlE Standards Commission (5th Eds.), Manual of Standards for Diagnostic Tests and Vaccines. Office International des Epizooties, Paris, France (Chap. 2.1.1).

11. Vangrysperre $W$ and De Clercq $K$ (1995): Rapid and sensitive polymerase chain reaction base detection and typing of footand-mouth disease virus in clinical samples and cell culture isolates, combined with a simultaneous differentiation with other genomically and/or symptomatically related viruses. National Institute for Veterinary Research, Brussels, Belgium. Arch Virol (1996) 141:331-344.

\section{Tamura K, Dudley J, Nei $M$ and Kumar $S$} (2011): MEGA5: Molecular Evolutionary Genetics Analysis (MEGA) software version 4.0. Molecular Biology and Evolution 24:1596-1599.

13.WRLFMD, (2009). WRL-FMD Quarterly Report January-March, 2012, Reference Laboratory Contract Report Institute for Animal Health, Pirbright Laboratory, United Kingdom.

14.WRLFMD (2012). WRL-FMD Quarterly Report January-March, 2012, Reference Laboratory Contract Report Institute for Animal Health, Pirbright Laboratory, United Kingdom website. 


$$
\text { الملخص العربى }
$$

المقارنة الجزينيه بين عترات الحمى القلاعية المعزولة حديثا و العترات المستخدمة في إنتاج اللقاح في مصر

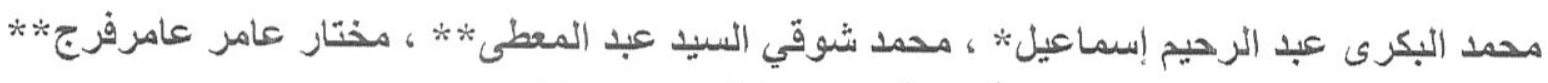

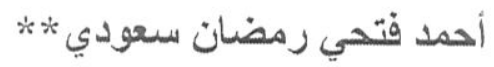

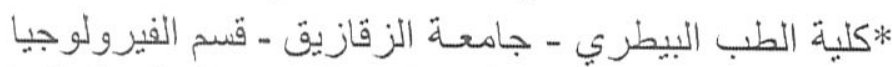

** قمم الحمى القلاعيةـ معهد بحوث الأمصال و اللقاحات البيطرية بالعباسيةـ القاهرة.

يعتبر مر ض الحمى القلاعية هن الامر اض المتوطنة فى مصر من عام .90 19. منذ هذا التاريخ تتابع

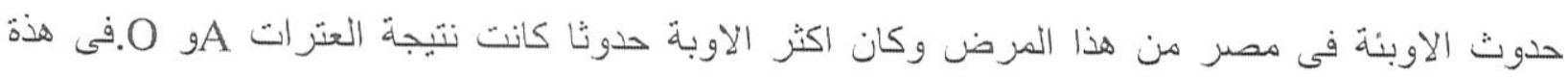

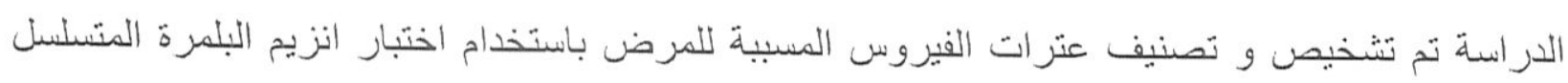

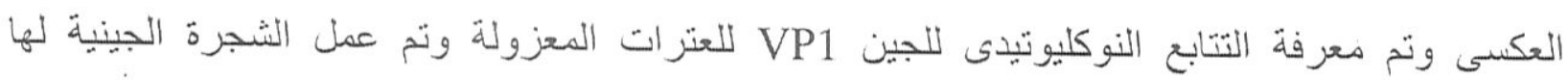
واوضحت النتائج أن عترة الفيروس O المعزولة تتبع ( O topotype ME-SA في جميح المناطق

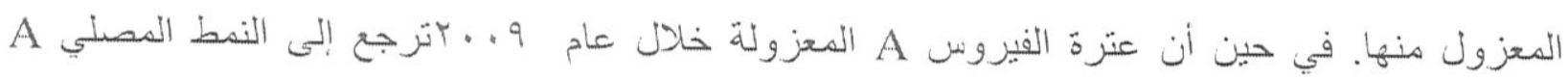
topotype

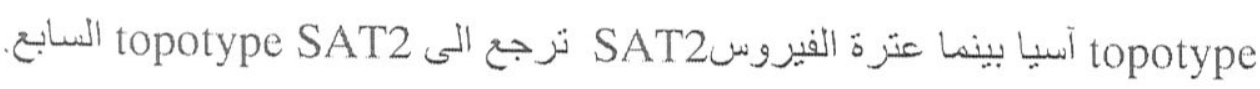

